\title{
Threatened fishes of the world: Gambusia eurystoma Miller, 1975 (Poeciliidae)
}

\author{
Michael Tobler • Martin Plath
}

Received: 24 October 2008 / Accepted: 16 April 2009 / Published online: 7 May 2009

(C) Springer Science + Business Media B.V. 2009

Common names: Widemouth mosquitofish (US), Guayacón del Azufre (MX). Conservation status: Designated 'critically endangered' by the IUCN based on highly localized occurrence, small area inhabited, and decline of habitat quality. The species is protected by Mexican law (SEDESOL 1994). Identification: Small-bodied mosquitofish closely related to G. sexradiata. It is characterized by having a compact body with short and rounded fins; a large head with a broad mouth; 30 scales in the lateral line; small black spots irregularly distributed on the ventral part of the body and the unpaired fins; and details in the gonopodium morphology (Miller 1975). Illustration by Madlen Ziege. Distribution: Only known from the Baños del Azufre (Río Grijalva system), west of Teapa, Tabasco and Chiapas, Mexico. Ecology: Gambusia eurystoma inhabits the outflow of hydrogen sulfide-rich springs, where it is locally abundant. Unlike Poecilia sulphuraria, with which the species co-occurs, G. eurystoma does not occur in the immediate spring areas, but prefers deeper areas with lower $\mathrm{H}_{2} \mathrm{~S}$ concentrations (Tobler et al. 2008). The substrate consists mostly of a

M. Tobler $(\bowtie)$

Department of Wildlife and Fisheries Sciences,

Texas A\&M University,

2258 TAMU,

College Station, TX 77843, USA

e-mail: michi.tobler@gmail.com

M. Plath

Institut für Ökologie, Evolution und Diversität,

Goethe Universität Frankfurt,

Siesmayerstr. 70-72,

60054 Frankfurt a.M., Germany

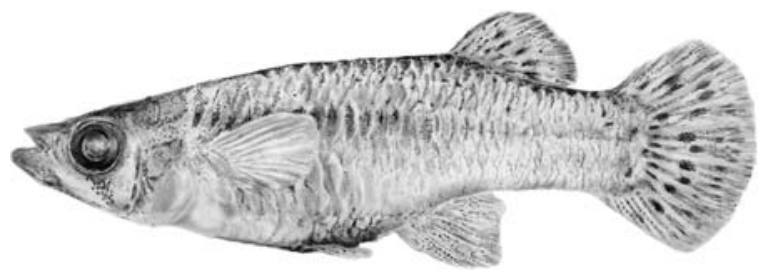

layer of anoxic mud. Threats: Gambusia eurystoma is threatened by intense habitat alterations. A hotel complex is situated in the immediate spring area and many of the springheads are used for recreational purposes. Intense cattle grazing altered the riparian vegetation of springs and outflow. Conservation recommendations: The species is protected by Mexican law, but no specific conservation actions have been taken. Steps should be taken to minimize the impact of and pollution by the recreational use of the springheads. A restoration of the riparian buffer is recommended.

\section{References}

Miller RR (1975) Five new species of Mexican poeciliid fishes of the genera Poecilia, Gambusia, and Poeciliopsis. Occ Pap Mus Zool Univ Michigan 672:1-44

SEDESOL (1994) NORMA Oficial Mexicana NOM-059-ECOL1994, que determina las especies y subspecies de flora y fauna silvestres terrestres y acuáticas en peligro de extinción, amenazadas, raras y las sujetas a protección especial, y que establece especificaciones para su protección. Diario Oficial 488:2-60

Tobler M, Riesch R, García de León FJ, Schlupp I, Plath M (2008) Two endemic and endangered fishes, Poecilia sulphuraria (Alvarez, 1948) and Gambusia eurystoma Miller, 1975 (Poeciliidae, Teleostei), as only survivors in a small sulfidic habitat. J Fish Biol 72:523-533 